\title{
The Eusebian and Meletian Roots of John Chrysostom's Trinitarian Theology
}

\author{
Pak-Wah Lai \\ Biblical Graduate School of Theology \\ laipw@bgst.edu.sg
}

\begin{abstract}
Chrysostom has often been regarded as an Antiochene theologian, who is more a pastor and moralist than a serious theologian. When we study his Chrysostom's Trinitarian doctrine, in the context of the Eusebian-Meletian traditions, a different picture emerges. Firstly, he has a well-thought-out theological epistemology and structure. His prioritisation of faith before reason, doctrine of divine incomprehensibility, endorsement of the Nicene homoousios formula, and use of hypostatic language as a safeguard against Sabellianism are strong evidence that he was operating within the Eusebian-Meletian lineages. Secondly, the ease by which he uses Eusebian and Homoian expressions indicates that he has embraced Meletius' reconciling stance. Most intriguingly, his Christological departure from Diodore calls into question his indebtedness to his teacher. When all these are taken into account, Chrysostom should be better understood as a Neo-Nicene Eusebian-Meletian theologian rather than a representative of the School of Antioch.
\end{abstract}

\section{Keywords}

Chrysostom - Trinity - Meletian - Eusebian - School of Antioch - Diodore of Tarsus

\section{Studies of Chrysostom's Trinitarian Theology: A Review}

Over the last century, resurging interest in Trinitarian theology has likewise piqued the attention of patristics scholars. ${ }^{1}$ Besides the important revisionist

1 For a survey of Trinitarian scholarship in the 2oth century, see S. Grenz, Rediscovering the Triune God: The Trinity in Contemporary Theology, Minneapolis, 2004. 
works of Lewis Ayres, John Behr and others on the history of the Nicene faith, several monographs have also been published on Trinitarian teachings of church fathers, such as Arius, the Eusebians, Marcellus of Ancyra, Augustine, Basil of Caesarea, Gregory of Nazianzus, and Hilary of Poitiers. ${ }^{2}$ Despite being one of the most well researched church fathers, John Chrysostom's Trinitarian theology has received surprisingly little attention. Over the last few decades, only two articles have been published on this subject. ${ }^{3}$ There are several reasons for this. Until recently, Chrysostom was often regarded as a Christian moralist and pastor, rather than a serious dogmatic theologian. As Hans von Campenhausen puts it,

Questions of dogma played scarcely any part in his life. [... Chrysostom] did not contribute to the dogmatic elaboration of Christological theory nor take much interest in the academic disputes of the day in this field. ${ }^{4}$

Compounding this bias is the nature of Chrysostom's writings. The majority of his works are occasional or exegetical homilies, which makes any systematic study of his theology all the more challenging. Even when Chrysostom makes homiletical forays into theological discussions, a substantial part of his sermon remains devoted to pastoral exhortations. Unfortunately, these features do not lend themselves well to the dogmatic approach of systematic theologians.

2 R. Williams, Arius : Heresy and Tradition, Grand Rapids Michigan, 2002; L. Ayres, Augustine and the Trinity, Cambridge, 2010); B. Sesboüé, Saint Basile et La Trinité, Un Acte Théologique Au rve Siècle: Le Rôle de Basile de Césarée Dans Lélaboration de La Doctrine et Du Langage Trinitaires, Paris, 1998; D.M. Gwynn, The Eusebians: The Polemic of Athanasius of Alexandria and the Construction of the 'Arian Controversy', Oxford, 2006; C. Beeley, Gregory of Nazianzus on the Trinity and the Knowledge of God: In Your Light We Shall See Light, Oxford, New York, 2008; C. Beckwith, Hilary of Poitiers on the Trinity: From De Fide to De Trinitate, Oxford, 2011; S. Parvis, Marcellus of Ancyra and the Lost Years of the Arian Controversy: 325-345, Oxford, 2009.

3 T. Karmann, "Johannes Chrysostomus Und Der Neunizänismus Eine Spurensuche in Ausgewählten Predigten Des Antiochenischen Presbyters," Sacris Erudiri, $5^{1}$ (2013): pp. 5-20; S.G. Papadopoulos, "The Holy Trinity and the Parousia of the Holy Spirit According to St. John Chrysostom," in: Agape and Diakonia. Essays: In Memory of Bishop Gerasimos of Abydos, Brookline, MA, 1998, pp. 97-125.

4 Even as late as 2013, Thomas Karmann concludes similarly that Chrysostom simply had no interest in speculative theology. H. von Campenhausen, The Fathers of the Church, Peabody, Massachusetts, 1998, pp. 140, 144. See also H. Rashdall, The Idea of the Atonement in Christian Theology, Being the Bampton Lectures for 1915, London, 1919, pp. 92 and D.S. Wallace-Hadrill, Christian Antioch: A Study of Early Christian Thought in the East, Cambridge, 1982, pp. 164; Karmann, "Chrysostomus." 
Finally, Chrysostom has been associated traditionally with the so-called School of Antioch, whose archetypal theologian is Theodore of Mopsuestia. ${ }^{5}$ Consequently, if one wants to find out more about 'Antiochene theology', particularly how it gave rise to the Nestorian controversy, and the post-Chalcedonian schism, their theologian of choice would be Theodore of Mopsuestia instead. This is because Theodore is regarded, quite rightly, by most as the pivotal figure behind both controversies. ${ }^{6}$ It is hardly surprising then that, proportionally speaking, there have been more studies of Theodore's theology than that of Chrysostom. ${ }^{7}$

\section{Chrysostom's Theological Legacy}

Yet this was not how the earlier Christians understood Chrysostom's theological legacy. As early as the fifth century, both Augustine and his Pelagian opponents found Chrysostom important enough to be cited as a supporter of their soteriologies. ${ }^{8}$ After Chalcedon, observes Pauline Allen, John Chrysostom's teachings were quoted time and again in the florilegia of both the pro- and anti-Chalcedonians as justification for their Christologies. ${ }^{9}$ Based on these alone, Chrysostom would have been one of the most ecumenical, if not influential, theologians in the fifth to sixth centuries.

5 Recent scholarship has questioned the legitimacy and helpfulness of the School of Antioch paradigm. Andrew Louth, for example, has rejected its existence on historical grounds. Andrew Louth, "Why Did the Syrians Reject the Council of Chalcedon?," in: Chalcedon in Context: Church Councils, 400-700, ed. R.M. Price, M. Whitby, Liverpool, 2009, pp. 108-9.

6 Theodore was anathemised in the Second Council of Constantinople (553), along with Theodoret of Cyrus and Ibas of Edessa, for propounding Nestorian ideas.

7 See, for example, R.A. Greer, Theodore of Mopsuestia: Exegete and Theologian, London, 1961; F.A. Sullivan, The Christology of Theodore of Mopsuestia, Romae, Apud Aedes Pont, 1956; F.G. McLeod, The Image of God in the Antiochene Tradition, Washington, D.C., 1999, F.G. McLeod, The Roles of Christ's Humanity in Salvation: Insights from Theodore of Mopsuestia, Washington, D.C., 2005; F.G. McLeod, Theodore of Mopseustia, London and New York, 2009.

8 Augustine, De Natura et Gratia 64 [Augustine, Four Anti-Pelagian Writings, trans. J.A. Mourant, W.J. Collinge, Washington D.C., 2001, pp. 82].

9 What is less known is that Chrysostom was highly esteemed by both the Monophysite bishop, Severus of Antioch, (512-518) and also the post-Chalcedonian Nestorians. Both parties cited him extensively in his homilies and letters. F.M. Young, From Nicaea to Chalcedon: A Guide to the Literature and Its Background, London, 1983, pp. 15o; P. Allen, "John Chrysostom after Chalcedon: A Useful Ecumenist?," in:John Chrysostom: Past, Present, Future, ed. D. Costache, M. Baghos, Sydney, 2017, pp. 53-70. 
More importantly, a mere moralist was not how Chrysostom regarded himself as a priest shepherding the flock of Christ. In his On the Priesthood, where he expounds the qualifications of priests, he devotes almost a third of his treatise to the priest's role as a teacher of the Word. A priest, who is entrusted with the Church of Christ, declares Chrysostom, "must train it to perfect health and incredible beauty." ${ }^{10}$ Indeed, he sees the ministry of the Word as more critical than being an exemplary pastor. This is because when a soul is afflicted by false doctrine,

there is only one means and only one method of treatment available, and that is teaching by word of mouth. That is the best instrument, the best diet, and the best climate. It takes the place of medicine and cautery and surgery [in the healing of the soul].11

What Chrysostom has in mind here is not merely the ability to exegete Scriptures, or to exhort one's flock. Rather, it is to possess a theological finesse that can fend off any kind of heretical assault on the Church. Using the metaphor of a siege, he explains that

as long as a city is encircled with walls all around, it mocks its besiegers and remains in perfect safety. But once a breach is made in the wall, no larger than a gate, the circuit is no more use to it, though all the rest stands safe. So it is with the City of God. As long as the nimble wits and the wisdom of the shepherd encompass it like a wall all round, all the enemy's devices end in his own shame... and the inhabitants remain unharmed; but when someone manages to break down a part of his defence, even though he fails to destroy it all, from that moment practically the whole city is ruined through that one part. ${ }^{12}$

For Chrysostom, such breaches include the attraction of Judaising behaviour, the Manichaean heresies, "the nonsense taught by Valentinus and Marcion," and "the madness of Sabellius or the ravings of Arius." ${ }^{3}$ Among these heterodox opponents, the most serious threat remains the Anomeans, now commonly known as the Heteroousians, whom Chrysostom encountered in Antioch and Constantinople.

\footnotetext{
10 sac. 4.2

$11 \quad$ Ibid. 4.3 (Translated by Neville, 115).

12 Ibid. 4.3 (Translated by Neville, 116).

13 Ibid. 4.3-4.
} 
When one surveys Chrysostom's homilies, it is clear that he was well- informed about and familiar with the issues involved in the Trinitarian debates. According to Stylianos Papadopoulos, Chrysostom not only

accepted the Homoousion of Nicaea, but was also familiar with the theology of the Cappadocians, at least in general. He particularly knew the distinction of the three divine Hypostases and the one nature in God. In fact, he was the first non-Cappadocian theologian to discern the absolute significance of this distinction, analysing and applying it broadly. This is obvious from the manner by which he understood the teaching about the Holy Spirit after St. Athanasios, contributing himself to its broadening by presupposing the theology of the three distinct divine Hypostases. ${ }^{14}$

While it is true that Chrysostom made ample use of, what is now regarded as, orthodox Trinitarian terminologies, it is far from clear whether and in what ways he was indebted to Athanasius, and the Cappadocians (or for that matter, which of three). With regards to the latter, recent studies of Basil and two Gregories have demonstrated, quite clearly, that their Trinitarian teachings are not as homogeneous as traditionally believed, and that their relationships with the Meletian faction (to which Chrysostom belonged) were not always straight forward. ${ }^{15}$ All these beg the question as to how we should assess Chrysostom's reception of the Cappadocians, if there is any. ${ }^{16}$

Thomas Karmann, I believe, is correct when he situates the roots of Chrysostom's Trinitarian theology to an earlier source: the teachings of the Meletian community in the early 360 s. Unfortunately, towards the end of his study, Karmann lapses back to the traditional view of Chrysostom by concluding that Chrysostom's dogma, while sufficient to address the needs of his audiences, is rather basic. This, he believes, is due to the Antiochene's deep scepticism of the

14 Later, Papadopoulos even goes so far as to regard Chrysostom as "a bearer of Cappadocian theology." Papadopoulos, "Holy Trinity."

15 Gregory of Nazianzus is a good example. While he was supposed to be the Meletians' representative at Constantinople, he turned out to be a sharp critic of the Christology of Diodore of Tarsus, one of the Meletian leaders. C. Beeley, 'The Early Christological Controversy: Apollinarius, Diodore, and Gregory Nazianzen', Vigiliae Christianae, 65 (2011), pp. 376-407.

16 The same is to be said about his relationship with Athanasius. While we know that Chrysostom did read the Life of Antony, it is uncertain whether he was influenced by Athanasius' pneumatology, and in what way. It would seem then that Papadopoulos has interpreted Chrysostom's theology anachronistically, in the light of Orthodox Trinitarianism. 
human ability to explore God's nature, and, thus, the value of theological speculation. ${ }^{17}$ It appears, however, that Karmann's assessment is based more on the bias of 2oth century European dogmatics than what is required of a late fourth century pastor-theologian, like Chrysostom. If Chrysostom is to be judged fairly, it should be on his own terms and circumstances. This then requires an examination of how he appropriated the teachings of his theological forebears.

In this paper, I would like to set the stage for a proper study of Chrysostom's Trinitarian teachings by delineating the ecclesial alliances caught up in the fourth century Trinitarian controversy, the theological issues that concerned them most, and which of these Chrysostom was most aligned with. Particular interest will be paid to the teachings of his mentors, Meletius of Antioch, and Diodore of Tarsus, though the latter to a lesser extent. Particular attention will also be given to his invectives against his foes, especially Sabellius. Based on an analysis of his Baptismal Instructions, it shall be seen that Meletius plays a far more important role in Chrysostom's Trinitarian theology than Diodore. For this reason, Chrysostom should be regarded more so as a Neo-Nicene Eusebian, or Meletian, theologian rather than a representative of the so-called School of Antioch.

\section{Ecclesial Alliances in the Fourth Century Trinitarian Controversy}

1

The Eusebians, Marcellus of Ancyra and Athanasius (320s to 340s)

In last two decades, the traditional account of the fourth century Trinitarian controversy as a debate between Athanasius (296-373) and the so-called Arians have largely been overturned. ${ }^{18}$ Instead, scholars now recognise that there were at least six ecclesial alliances vying for Trinitarian orthodoxy between the Councils of Nicaea and Constantinople. ${ }^{19}$ The first were the Eusebians, led by and named after Eusebius of Nicomedia (d. 341), and included Eusebius of Caesarea, Theodotus of Laodicea and Asterius the Sophist. ${ }^{20}$ Although their teachings were not monolithic, these Eastern fathers' teachings share a familial resemblance. A good example of their theology is that of Eusebius of

\footnotetext{
$17 \quad$ Karmann, "Chrysostomus."

18 J. Behr, The Nicene Faith, vol. 2, Crestwood, NY, 2004, pp. 22.

19 I follow Delcogliano here who defines an ecclesial alliance as a group which arises "because of some common value or are formed for the promotion of a specific agenda in the ecclesiastical sphere." M. Delcogliano, 'The Death of George of Laodicea', JTS, 60 (2009), pp. 181-90.

20 Gwynn, Eusebians., pp. 111.
} 
Caesarea, who distinguishes the Father and the Son by depicting the Father as "the unbegotten (aggenètos), eternal source of all," while the Son as deriving "his existence from the Father," and is thus "not co-eternal with him."21 This being said, Eusebius maintains that the two shares a unique and intimate relationship, where the Son is "like the Father with the greatest degree of exactness possible, being in himself the whole form of God." Eusebius is among the first to use the term, hypostasis, to denote the "independent ontological existences" of the Father and the Son. He would be followed by Asterius, his successor, who applies the term to the Holy Spirit and declares "the Father, Son and Holy Spirit as three distinct hypostases." More importantly, the Eusebians "distrusted the language of the Nicene Council and above all the term homoousios, which they believed implied a materialist and modalist conception of God."22 This is also why they regarded Marcellus of Ancyra's teachings as neo-Sabellian and deviant.

In contrast, Marcellus of Ancyra (285-374) held the preservation of God's unity as the utmost concern in Trinitarian discourse. Consequently, he frequently downplays the Father-Son language, by portraying God as "a unitary divine monad that mysteriously expanded into a triad (namely, the Word and Spirit), without losing its essential oneness and indivisibility." Unsurprisingly, Marcellus was also adamant that no duality be posited for God, whether this is speaking of Him as being "two substances, two hypostases, [or] two powers."23 For the Eusebians, Marcellus' teachings smack of Sabellianism, and they moved swiftly to depose him. The exiled bishop then made his way to Rome where he allied with Athanasius, who was serving his second exile there. ${ }^{24}$

In all likelihood, it was in Rome that Athanasius composed his Orations against the Arians (c. 341) where, for the first time, he attacked and labelled the theologies of Arius, Eusebius of Nicomedia, and others as 'Arian'. Contrary to

The designation, "Unbegotten," has been in use since previous centuries to designate the Father. Mark Delcogliano and Andrew Radde-Gallwitz, 'Introduction', in Against Eunomius, vol. 122, Fathers of the Church (Washington, D.C.: Catholic University of America Press, 2011)., 22-24; M. Delcogliano, 'Influence of Athanasius," JECs, 19 (2011), pp. 197-223.

22 Gwynn, Eusebians., pp. 246-47.

23 Delcogliano and Radde-Gallwitz, "Introduction," pp. 22-24. For a detailed treatment of Marcellus' theology see Parvis, Marcellus of Ancyra, pp. 8-37.

24 The Fourth Oration Against the Arians and its explicit condemnation of Marcellus is no longer regarded as a work of Athanasius. This being said, Athanasius did break communion with Marcellus briefly (c. 344). The two, however, reconciled subsequently. J.T. Lienhard, M. Barnes, R. Williams, “Did Athanasius Reject Marcellus?,” in: Arianism after Arius: Essays on the Development of the Fourth Century Trinitarian Conflicts, Edinburgh, 1993, pp. $65,78-79$. 
the Eusebians, Athanasius believes that the Son's status as the only begotten of the Father marks him out as not only radically different from all creatures, but as, in fact, co-eternal and one with the Father. He also differs from Marcellus by maintaining that Father and the Son should be distinguished from one another. Athanasius, however, does not go as far as the Eusebians by developing a technical vocabulary to articulate this difference. ${ }^{25}$ It is noteworthy that, by this time, the Eusebians had gathered significant political clout, so much so that the confessions promulgated at a council in Antioch (the 'Dedication Council' of 341) would become "the basis of eastern conciliar statements" over the next two decades. ${ }^{26}$

Despite the dominance of the Eusebians in the East, it should be observed that not a few fathers remained sympathetic to Marcellus' teachings. Besides Athanasius and his Egyptians peers, there were also the participants of the Western Council of Sardica (343), bishops in Greece and Macedonia, the Marcellans of Ancyra (who persisted even in 37os), and the Eustathians-Paulinians of Antioch. Many of these were Miahypostasians, who shared a common aversion to describing God in terms of more than one hypostasis, and regarded the language of one hypostasis to be the best safeguard against any subordinationist understanding of the Father, Son and the Spirit. ${ }^{27}$

\section{$2 \quad$ Homoiousians, Homoians, and Heterousians (340s to 350s)}

The years 340 s to 350 s saw attempts by the Western and Eastern bishops to forge a theological consensus, but to no avail. An initial council was proposed at Serdica (343) but did not take place. This was because the bishops not only refused to meet, but even excommunicated each another. Subsequent councils held in Sirmium (351), Arles (353) and Milan (355) maintained a Eusebian stance by condemning Marcellus along with his allies, Athanasius and Photinus. The 35 os saw this aversion to Marcellan teachings evolved further when several Eusebians became reluctant to employ any form of ousia language to describe God. Eventually, this splintered the Eusebian alliance into three factions: the Homoians, Heteroousians, and the Homoiousians.

\footnotetext{
25 Delcogliano and Radde-Gallwitz, "Introduction," pp. 24-26.

26 Delcogliano, "The Death of George of Laodicea," pp. 679.

27 As we shall see, Basil will take this miahypostasis stance to task in his later writings. J.T. Lienhard, "Ousia and Hypostasis: The Cappadocian Settlement and the Theology of 'One Hypostasis," in: The Trinity: An Interdisciplinary Symposium on the Trinity, ed. S. Davis, D. kendall, and G. O'Collins, Oxford, 2002, pp. 114-18.
} 
The Homoians came into prominence at the Council of Sirmium (357), when a small group of bishops issued a Homoian confession that condemned all use of ousia-language, whether homoousios or homoiousios (like in substance'). Instead, they preferred to speak of the Son as being like (homoios) the Father. Their new creed sent shockwaves across the Eastern provinces as it tantamount to rejecting the Eusebians' Dedication Creed (341), which affirmed the Son to be the image of the Father's ousia. ${ }^{28}$ The same year also saw Eudoxius becoming the Bishop of Antioch, and ratifying the Sirmium confession, thereby establishing Antioch as a Homoian base camp. More seriously, he invited Aetius who would advocate a radical form of Homoian teaching in the city: Heteroousian theology, which declares the Son to be 'different in substance (heteroousios) from the Father. ${ }^{29}$ Anxious to head off the Homoians and Heteroousians, George of Laodicea (d. 359) rallied other Eusebians, most notably Basil of Ancyra (d. 362), to produce a Homoiousian confession in Ancyra (358), which asserted their preferred depiction of the Son as "like the Father in

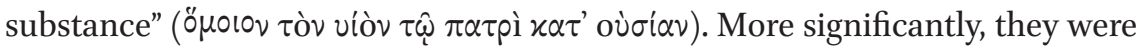
able to convince Constantius to depose and banish Eudoxius, Aetius and Aetius' protégé, Eunomius. Their successes were short-lived, however. In 359, Constantius convened another council to formulate a new creed (the 'Dated Creed') which, on the surface, accommodated both Homoian and Homoiousian concerns. In reality, it favoured the Homoian position by declaring the Son to be "like the Father in all respects," and condemning all use of ousia language. The Homoiousians were finally outflanked a few months later, when they were obliged to endorse a modified Dated Creed - the Creed of Niké, which omitted "in all respects," and thus ruling out Homoiousian theology altogether. This set the stage for the Council of Constantinople (360) which deposed all Homoiousian leaders, including Basil of Ancyra.

The fortunes of the Heteroousians were more mixed. While Aetius remained condemned, Eudoxius was reinstated, and even promoted to the bishopric of Constantinople. As for Eunomius, he managed to convince others of his orthodoxy, and was appointed the Bishop of Cyzicus. Heteroousian influence thus remained unabated, if not increased in the East. ${ }^{30}$ Judging by Chrysostom's experience in Antioch and Constantinople, this was to persist even until the $390 \mathrm{~s}$.

\footnotetext{
28 Behr, Nicene Faith, vol. 1., pp. 87-88

29 M. Delcogliano, “George of Laodicea: A Historical Reassessment," JEH, 62 (2011), pp. 66792.

Delcogliano and Radde-Gallwitz, "Introduction," pp. 28-33.
} 


\section{The Neo-Nicene Meletians}

$1 \quad$ The Rise of the Neo-Nicene Meletians

In the aftermath of the Nicene Council, Eusebius of Caesarea managed to depose Eustathius of Antioch (324-330), a Nicene supporter, on Sabellian charges (327). The see of Antioch thus fell into Eusebian hands in the next three decades, even though a small sect of Eustathian supporters, led by Paulinus, endured..$^{31}$ Although Eudoxius' election saw Antioch slip into Homoian control, his translation to Constantinople (360) ushered in a sea change: his successor, Meletius, turned out to be more homoiousian than expected. ${ }^{32}$ While Meletius was deposed quickly, he was able to return a year later to convene the proNicene Synod of Antioch (363). ${ }^{33}$ Unfortunately, this did little to unite the proNicene factions in Antioch. This was because the Eustathians had elected Paulinus as a competing bishop during Meletius' absence (c. 362). ${ }^{34}$ Things would worsen a decade later when Apollinarius appointed Vitalis as a third competing bishop in 376. Counting Euzoius, the Homoian bishop, this brought the total claimants to the Antiochene see to four!

Efforts to reconcile the Meletians and Paulinians, first by Athanasius through his Tome to the Antiochenes (362), and later by Basil of Caesarea (370s) bore no fruit. To make matters worse, Meletius fell out with Athanasius after he refused communion with the Bishop of Alexandria (late 363), due most likely to Athanasius' support for Marcellus. ${ }^{35}$ In the years that followed, Meletius was exiled twice more, between $365-367$, and 371 to 378 . The Meletian faction did not falter, however, due to the capable leadership of Flavian and Diodore of Tarsus. ${ }^{36}$ When he finally returned in 379, Meletius was instrumental in not only shoring up support for the Nicene cause, but also convening of the Second Ecumenical Council (381). In so doing, the Meletians played a significant role in the triumph of Nicene orthodoxy.

$31 \quad$ For ease of reference, we will be referring to Eustathius' followers as Paulinians, after Paulinus, who will lead them from the 360 s onwards. Behr, Nicene Faith, vol. 1, pp. 30. T.R. Karmann, Meletius von Antiochien: Studien Zur Geschichte Des Trinitätstheologischen Streits in Den Jahren 360-364 N. Chr., Frankfurt, 2009, pp. 57-59. Socrates, Eccl. Hist. 3.25; J. Zachhuber, "The Antiochene Synod of AD 363 and the Beginnings of Neo-Nicenism," ZAC, 4 (2000), pp. 83-101.

34 J.N. D Kelly, Golden Mouth: The Story of John Chrysostom - Ascetic, Preacher, Bishop, Ithaca, N.Y., 1995, pp. 12.

35 Beeley, Gregory of Nazianzus., 28-29; Lienhard, 'Ousia and Hypostasis', 109.

36 Diodore would also be exiled from 372-378. Behr, Nicene Faith 1., 98. 


\section{$2 \quad$ Meletius' Early Theology in his Homily on Proverbs 8:22}

Shortly after his election, Meletius preached a homily on Proverbs 8:22 at a preaching contest with Acacius of Caesarea. ${ }^{37}$ His Trinitarian ideas, as we shall see, proved too homoiousian for his Homoian sponsors, and they deposed him promptly. Both Theodoret and Epiphanius have regarded his homily as 'canonical' and 'orthodox'. It should be observed, however, that the sermon mentions neither the Nicene Council nor its homoousios formula. ${ }^{38}$ Notwithstanding this, it provides valuable insights into Meletius' early theological sentiments.

The homily itself is divided into three parts, the opening section being the shortest. It is here that we find the heart of Meletius' message, which is to urge the different Antiochene parties to reconcile and unite so that there is "no schism in the body [of Christ]," and peace may reign in the Church. ${ }^{39}$ It is here also that Meletius introduces his Christology when he declares that such peace seekers are those who keep Christ's commandments, and they do so only because their "eyes or hearts" have been enlightened by Christ speaking within them. This same Christ, he continues, shares the glory of God that has been declared by the heavens (Psalm 19), and is the means by which one knows the Father. To bolster his arguments, Meletius then quotes from 1 John 2:22-24 - "he that acknowledges the Son acknowledges the Father also," and concludes that this is how a Christian abides in both the Son and the Father. ${ }^{40}$ What we have here appears to be an epistemic argument for the Son's divinity. That is, the Son is like, if not equal to the Father, because it is through Him only that one can know the Father.

Thereupon, Meletius produces a detailed confession of his faith.

the Son of God is God of God, One of One, Only-begotten of Ingenerate, the elect Offspring of his Begetter and a Son worthy of him who has no beginning; the ineffable Interpreter of the Ineffable, the Word, and the Wisdom and Power of Him who transcends wisdom and power, beyond anything that the tongue can utter, beyond any thought the mind can initiate. He is the perfect and abiding Offspring of Him who is perfect, and abides the same - not an overflow of the Father or a bit or piece of

This is according to Theodoret. Although Epiphanius of Salamis, who preserves the homily for us, makes no mention of the preaching contest, there is internal evidence for Theodoret's claim: the homily itself refers to "those who have spoken before me." Theodoret, HE 2.31-6-8; Sozomen, HE 4.28.6-10; Epiphanius, Panarion 53.31.2.

38 Socrates does not mention the sermon but claims likewise that Meletius was exiled because of his support for the homoousios. Ibid.; Sozomen, HE 4.28.6-10; Socrates HE 2.44.

$40 \quad$ Ibid. $53.29 \cdot 6-30.3$. 
the Father, but come forth without passion and entire, from him who has lost none of what he had. And because [the] Son is, and is called, the "Word," he is by no means to be conceived of as the Father's voice or verbal expression. For he subsists in himself and acts, and by him and in him are all things. Similarly, although he is Wisdom as well, he is not to be conceived of as the Father's thought, or as a movement and activity of his reason, but as an Offspring who is like the Father and bears the exact impress of the Father. For the Father, God, has sealed him; and he neither inheres in another nor subsists by himself, but [is] an Offspring at work, who has made this universe and preserves it. This is sufficient to free us from the error of the Greeks, the willful worship of the Jews, and the heresy of the sectarians. ${ }^{41}$

In her helpful analysis of Meletius' confession, Kelly Spoerl concludes that it "eludes strict classification." This is because it combines different theological elements drawn from Eusebian, Homoian and Homoiousian traditions, coupling them with a strong Anti-Marcellan polemic. For instance, the phrase 'God of God' is found not only in the Nicene creed, but "in virtually every eastern creed published from the time of the Antiochene Dedication in 341 to the council of Constantinople in 36o." As for the 'Ingenerate' (agennētos), it is a Eusebian motif commonly employed in their anti-Marcellan polemic, though its recent use by the Eunomians may have rendered the word more problematic. ${ }^{42}$ Meletius' depiction of the Son as the "ineffable Interpreter of the Ineffable," finds a parallel in the Homoiousian synodal statement of 359. His distinction of the divine subjects as two 'ineffables' is again another safeguard against Marcellanism. As for the confession's exact sequence of Christ's titles - Word, Wisdom and Power, it appears also in several other Greek creeds. Finally, his frequent portrayals of the Son as being "like the Father," resonate well with Homoian dogma. Interestingly, what is missing is the Eusebian description of the Father and the Son as distinct hypostases. In view of these varied characteristics, Spoerl concludes that Meletius' theology, at this stage, is "a Ho-

41 Ibid. 53.30.4-7 [Translated by Williams in Epiphanius, The Panarion of Epiphanius of Salamis, Leiden, 2013, pp. 475-76.

42 K.M. Spoerl, "The Schism at Antioch since Cavallera," in: Arianism after Arius : Essays on the Development of the Fourth Century Trinitarian Conflicts, ed. M. Barnes, R. Williams, Edinburgh, 1993, pp. 111-12. 
moiousian one couched in cautious Homoian terms." Or to put it differently, it is a reconciling Eusebian position, with a Eusebian bias thrown in. ${ }^{43}$

Studies of Meletius' homily have focused mostly on his confession. I believe, however, that the third and final section of his homily is also an important aspect of his Trinitarian doctrine. For it is here that he expounds a doctrine of divine incomprehensibility which would be taken up by Chrysostom. In the conclusion of his homily, Meletius reminds his audience that

it is not possible to find in this world an example adequate in itself to explain clearly the nature of the Only-begotten. ... And for this reason, the scripture employs many ideas and terms with reference to the Onlybegotten, to help us grasp things. ...[and] imagine things we do not know by means of things we do; and to advance, gently and by easy stages, from the seen to the unseen. ${ }^{44}$

Clearly, for Meletius, effable concepts do have real reference to, and can help us understand, to some extent, the ineffable nature of God. This being said, he also believes that there are limits to creaturely analogies. Thus, when depicting the Son as the image of the Father, we should remember that

He is an image, not as an inanimate object is the image of a living thing or as a process is the image of an art, or a finished product the image of a process, but [as] an offspring is the image of its parent. And [we should know] that the generation of the Only-begotten before the ages may not lawfully be portrayed [along the lines of] bodily human generation. ${ }^{45}$

In all our discourse about the "incomprehensible" and "unsearchable" God, therefore, we must be cautious not to "fall into the depths of impiety," but remember always that it is faith that gives rise to theology, not vice versa. Since our knowledge of God will always be partial and imperfect, we must "cease to wrangle over the questions in dispute and the matters that are beyond us, and hold fast what we have received." Like Abraham (and not Zacharias) then, we

Likewise for the 'One of One' motif, which seems to be a variation of the formula that "appears in the second Antiochene creed of 341, the Homoian creeds of Sirmium 359, Nike 359, Rimini 359 and Constantinople 360, as well as in Basil of Ancyra's Homoiousian synodal statement of 358." Spoerl., 111-14, 123-26.

44 Epiphanius, Panarion 53.31.3-4 (Williams, pp. 476)

45 Ibid. 53.31.5-7 (Williams, pp. 477). 
recognise always that we are but "dust and ashes" whenever we speak to (or about) God. ${ }^{46}$

\section{$3 \quad$ The Tome to the Antiochenes}

Shortly after Meletius' return from his first exile, the Alexandrians composed the Tome to the Antiochenes (362) to persuade the Paulinians and Meletians to reconcile. Scholars have differed whether this document represents accurately the beliefs of the Meletians. Johannes Zachhuber, for example, doubts that a Meletian delegation was ever present in the synod, and thus questions its reliability. ${ }^{47}$ It is hard to believe, however, that Athanasius and his peers would wager a cause as important as healing the Antiochene schism on less than reliable information. At the very least, the Tome's contents should provide a rough sketch of the teachings that the Meletians would have approved of.

The Tome begins by praising the Paulinians and Meletians as those who "anathematise the Arian heresy and confess the faith confessed by the holy fathers at Nicæa, and ... also those who say that the Holy Spirit is a creature and separate from the substance (ousia) of Christ." It then goes on to claim that the two factions also oppose the "impiety of Sabellius and of Paul of Samosata, ... the madness of Valentinian and Basilides, and the folly of the Manichæans." 48 Following which, it describes those in the 'Old Church' (that is, the Meletians)

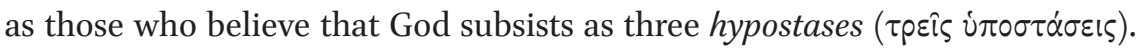
The authors clarify, however, that the Meletians' dogma is orthodox because

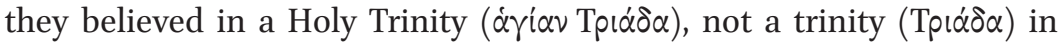
name only, but existing and subsisting in truth, 'both a Father truly exist-

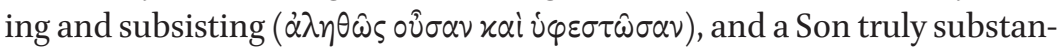

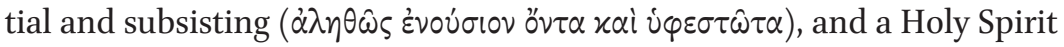

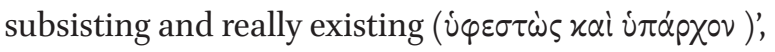

while maintaining "that neither had they said there were three Gods or three beginnings, nor would they at all tolerate such as said or held so, but that they acknowledged a Holy Trinity but One Godhead, and one Beginning, and that the Son is consubstantial with the Father ( $\dot{\alpha} \gamma \dot{i} \alpha \nu \mu \dot{\varepsilon} \nu$ Tp $\alpha^{\prime} \delta \alpha, \mu i \alpha \nu \delta \dot{\varepsilon} \theta \varepsilon \delta$ c $\eta \tau \alpha, x \alpha i$

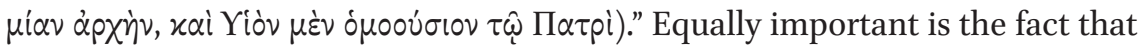

\footnotetext{
$46 \quad$ Ibid. 53.32.4-33.1-4.

47 Zachhuber, for example, doubts that they were there. Zachhuber, "Antiochene Synod of AD 363," pp. 93.

48 It is not insignificant that this same list was repeated later, after the orthodoxy of both parties was established. Tomus ad Antiochenos, 5-6.
} 
they affirm that "the Holy Spirit is not a creature, nor external, but proper to

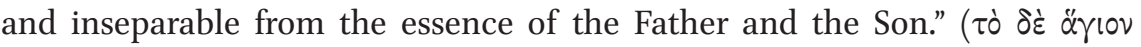

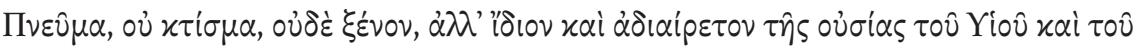
Патро́s). ${ }^{49}$

For Alexandrians, there appears to be grounds for believing that the Meletians were ready to adopt the Nicene creed and its homoousios formula. Equally significant is the fact that the Alexandrians could also reconcile the Eusebian language of hypostasis with Nicene orthodoxy. Another intriguing fact is that Meletian orthodoxy is established here by not only its adherence to the Nicene creed, but its affirmation of a catalogue of heresies ranging from Sabellianism to Manichaeism - a list likewise assumed for the Paulinians. Finally, Alexandrian motifs are also observed in the Tome, particularly, the use of the term, Trinity (trias), which occurs frequently in Athanasius' writings, but is absent from Meletius' homily on Proverbs 8:22 and the Antiochene Synodal confession (363) below. ${ }^{50}$ While we have yet to establish Meletius' influence on Chrysostom at this stage, it is noteworthy that there are clear parallels between the Tome's teachings and that of Chrysostom. Like the Tome, Chrysostom employs the three hypostases formula readily, and saw it as compatible with the Nicene creed. Besides his frequent use of the Trinity motif, Chrysostom's catalogue of heresies, often listed in conjunction with his Trinitarian discourse, are also remarkably similar to that of the Tome. ${ }^{51}$ Apart from the Judaisers, Manichaeans, Valentinians, and Arians, the Sabellians are also taken to task regularly in his homilies.

\section{$4 \quad$ The Synod of 363}

If there were any doubts about Meletius' theological allegiance, these were soon put to rest at the Synod of Antioch (363). This council was significant in two ways: the Meletians and Acacius, the leader of the Homians, were not only able to agree on a joint confession but were also willing to throw their weight

49 Tomus ad Antiochenos, 5-6.

50 The word, Trinity (trias in Greek and trinitas) was first used in Christian theology around the late second century by Theophilus of Antioch (Autol 2.15) and Tertullian (Adv. Praxeam 25). In the fourth century, it is also a term commonly employed in Athanasius' writings. Trias alone occurs 81 times in the Athanasian corpus. See, for example, Contra Sabellianos ( $P G$ 28.108.43, 28.116.20)

$5^{1} \quad$ Chrysostom employs the Trinity motif in no less than three occasions. The parallels between Chrysostom's teachings and those of the Tome also suggests intriguingly that he could have been influenced by Alexandrian teaching. The limits of this essay, however, does not allow us to explore this further. See In epistulam ad Romanos (PG 60.519.5); In Joannem (PG 59.424.3); Catecheses ad illuminandos 2.26.14. 
behind the Nicene Council and its homoousios formulation. This unprecedented cooperation was motivated most likely by their shared concern for curbing the growing popularity of heteroousian theology. ${ }^{52}$ At this synod, both parties declared that

we embrace and steadfastly hold the faith of the holy Synod formerly convened at Nicæa. Especially since the term homoousios, which to some seems novel and inappropriate, has been judiciously explained by the fathers to denote that the Son was begotten of the Father's substance,

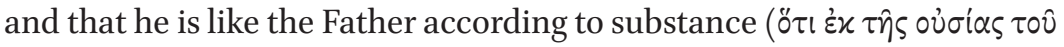

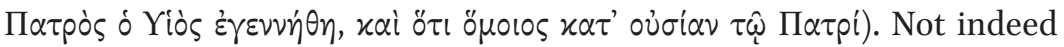
that any passions are to be understood in relation to that ineffable gen-

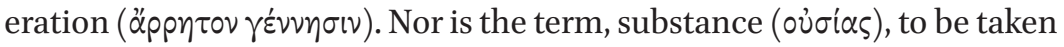
by the fathers in any usual signification of it among the Greeks; but it has been employed for the subversion of what Arius impiously dared to assert concerning Christ, viz. - that he was made of things not existing. Which heresy the Anomœans, who have lately sprung up, still more audaciously maintain, to the utter destruction of ecclesiastical unity. We have therefore annexed to this our declaration, a copy of the faith set forth by the bishops assembled at Nicæa, with which also we are fully satisfied. It is this: We believe in one God the Father Almighty, and all the rest of the Creed in full. ${ }^{53}$

In his analysis of the confession, Johannes Zachhuber concludes that the creed is largely in agreement with or could even be dependent on Athanasius' teachings. It begins by affirming the Nicene council without mentioning, or even deliberately excluding the other councils held from 340 os to 360 . Thereafter, it interprets the homoousios formula in both Athanasian and Eusebian terms. The Son as "begotten of the Father's ousia" (Athanasian) is now taken as equivalent to him being "like the Father according to ousia" (Eusebian). The latter thus safeguarding the former against Marcellan interpretations. The claim that the "ineffable generation" is without passion is straightforward, since it is already endorsed by most parties as a safeguard against a materialistic conception of the Son's begetting. The qualification that ousia should not be interpreted according to the understanding of the Greeks refers mostly likely to pagan teaching on ontology. More importantly, its language is very similar to that of Athanasius's De Synodis 51.3. In both cases, the key concern is to avoid

$5^{2}$ Zachhuber, "Antiochene Synod of AD 363," pp. 83-84.

53 Socrates, $E H$ 3.25.36-41 
"positing an entity which is ontologically prior" and therefore superior to the two divine subjects. This difficulty, quite understandably, is one of the most common criticisms of the Nicene formula. ${ }^{54}$

\section{$5 \quad$ The Paulinians}

Our study of Meletius' theology remains incomplete until we consider that of the Paulinians, which must have informed the bishop's doctrinal and polemical concerns. By and large, the Paulinians kept to Eusthathius' teachings and propounded a miahypostatic understanding of the Trinity. If the Tome was correct, their miahypostatic stance was not meant to be understood in Sabellian terms. Nonetheless, it continued to leave them open to heresy charges..$^{55} \mathrm{Just}$ a decade later, Basil of Caesarea would take them to task for describing God as "three prosoppa" without identifying this with the three hypostases formula. The former expression alone, he explains, is inadequate for safeguarding the real distinction between the divine subjects. By refusing to equate prosōpon with hypostasis, the Paulinians were creating inadvertently an unnecessary stumbling block for the Nicene cause. ${ }^{56}$

\section{$6 \quad$ Neo-Nicene Eusebian-Meletian Theology}

To conclude, what then are the key features of Meletius' Trinitarian theology at the eve of the Constantinopolitan Council (381)? If he adhered to the tenor of his early homily, Meletian's approach, broadly speaking, is Eusebian and reconciliatory. This is why his confession is laden with theological motifs from both the Homoian and Homoiousian factions and includes their characteristic bias against Sabellian or Marcellean teaching. In due course, his Trinitarian

54 While the synod marks the Meletians' transition into a Neo-Nicene party, it did not heal the Antiochene schism, as might be expected. The synodal proceedings were, in fact, criticised by Ps-Athanasian treatise, Refutation of the Hypocrisy of Meletius and Eusebius of Samosata, composed most likely by the Paulinians. Zachhuber, "Antiochene Synod of AD 363," pp. 88-92; Karmann, Meletius von Antiochien, pp. 445.

55 The Tome notes that the Paulinians did not intent to negate "the Son and the Holy Spirit, or [taught] as though the Son was non-substantial ( $\dot{\alpha} v v^{\circ} \sigma$ ív), or the Holy Spirit imper-

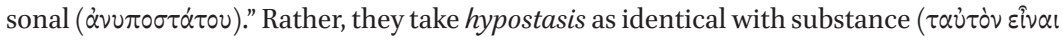

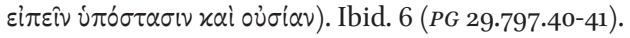

56 For Basil, prosōpon appears to denote what the English word, persona, means. Thus, one can be a teacher, father and a husband but remains a single subject. Consequently, the Paulinians' endorsement of the three prosōpa is compromised as long as they adhered to the expression of one hypostasis of the Father and of the Son and of the Holy Spirit"

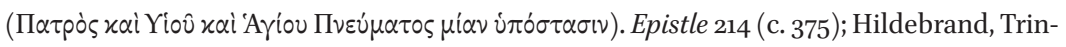
itarian Theology of Basil, pp. 86-87. 
teachings would be augmented by his ratification of the Nicene creed and its homoousios formula. Beyond this, we should also note his theological epistemology: that faith always precedes theological understanding, and all theological reflections must presume, as a starting point, a doctrine of divine incomprehensibility.

\section{The Trinity in Chrysostom's Baptismal Instructions}

Having laid out the contours of Meletius' Trinitarian teachings, we can now evaluate Chrysostom's reception of this tradition, as given in his Catechetical Homilies. Prior to this, it is helpful to review and reconsider Chrysostom's relationships with his mentors, Meletius and Diodore.

\section{$1 \quad$ Chrysostom and His Mentors}

Due to his association with the 'School of Antioch', it is often taken for granted that Chrysostom's theological leanings is indebted mostly to Diodore of Tarsus. Yet, if we scrutinise his early life, there is reason to believe that Meletius was the more significant mentor. Meletius and Chrysostom met around 367 , after the bishop returned from his second exile. Impressed by the young lad's intellect, virtue and interest in "divine learning," Meletius took him under his wings, baptised him, and made him a lector soon after. It was during the same period (c. 367-369) that Chrysostom and Theodore of Mopsuestia, enrolled in the asketerion headed by Diodore and Carterius. ${ }^{57}$ While little is known about Carterius, Diodore was a well-respected teacher among the Meletians. This is due largely to his leadership in the Nicene faction while Meletius was away in exile $(361-362,363-367)$. Chrysostom, however, was unlikely to have spent more than five years at the asketerion. This is because both Meletius and Diodore were exiled by 372 . Thereafter, we know dreadfully little about what happened to the asketerion between the years 372 to 378 . Devoid of its key leaders, the school may well have waned or even discontinued for some time. This was, perhaps, why Theodore lapsed briefly to pursue the prospect of marriage, while Chrysostom went to live a life of solitude up in the Syrian mountains (372-378), if we believe Palladius' account. ${ }^{58}$

57 Palladius, Dial. 5; Socrates, $H E$ 6.3; Sozomen $E H$ 8.2; Kelly, Golden Mouth, pp. 17.

$5^{8}$ Traditionally, scholars have taken their cue from Palladius, who claims that Chrysostom spent six years pursuing a life of solitude up on the Syrian mountains. This is despite the fact that other sources, namely, Sozomen, Socrates, and Ps-Martyrius, make no mention of this story. More recently, Martin Illert has argued that Palladius may well have 
Notwithstanding the doubts about Chrysostom's 'mountain stint', the young ascetic reunited with Meletius and Diodore in 378 after their return from exile. The next decade would see Chrysostom and Theodore follow different paths of ministry. Theodore was ordained in 383 and went on to serve under Diodore in Tarsus, until his appointment as Bishop of Mopseustia in 392.59 Chrysostom, on the other hand, remained in Antioch, where he ministered under Meletius (378-381), and, later on, Flavian. ${ }^{60}$ All in all, Chrysostom spent about eight years with Meletius (367-372, 378-381), compared to his five with Diodore. Theodore's allegiance to Diodore, on the other hand, runs deeper since he followed his teacher to Tarsus and understudied him for another nine years (383-392). This also explains the strong affinities between Diodore's theology and that of Theodore's. A similar influence, I believe, can be postulated between Meletius and his protégé. This becomes evident when we analyse Chrysostom's Catechetical Homilies in the light of Meletius' teachings.

\section{$2 \quad$ Trinitarian Discourse in the Catechetical Homilies}

Chrysostom's Catechetical Homilies were delivered in Antioch around 388390. ${ }^{61}$ Among them, Instruction 1 provides the most detailed exposition of Chrysostom's Trinitarian beliefs. The homily begins with the assertion that "faith is the foundation of piety." ${ }^{2}$ Following which, Chrysostom declares that we

projected his own Egyptian monastic experience onto Chrysostom's biography. He proposes instead that Chrysostom's ascetic experience was primarily urban. While recognizing the apologetic intent of the story, I am of the opinion that, given Palladius' general reliability in many aspects of Chrysostom's life, there is no reason why his claims should not be taken as true. M. Illert, Johannes Chrysostomus und das antiochenisch-syrische Mönchtum: Studien zu Theologie, Rhetorik und Kirchenpolitik im antiochenischen Schrifttum des Johannes Chrysostomus, Zürich, 2000. For an assessment of Illert, see J.H.W.G. Liebeschuetz, Ambrose and John Chrysostom, Oxford, 2011, Kindle Edition, Loc. 1069-84.

59 McLeod, Theodore of Mopseustia, pp. 4.

60 Liebeschuetz, Ambrose and John Chrysostom, Loc. 89 .

61 The first eight instructions are based on Wenger's Jean Chrysostome, Huit Catéchèses Baptismales Inédites, trans. Antoine Wenger (Paris: Ed. du Cerf, 1957)., which are based on the Stavronikita series. Instruction 9 is based on the Montfaucon series 1 (Ad illuminandos catechesis prima et altera, PG 49.221-40) and Papadopoulos-Kerameus (PK) series 1, Instructions 10 and 11 on PK 2 and 3 respectively, and Montfaucon 2 (PG 49.221-40). For a discussion of the manuscript tradition see John Chrysostom, Baptismal Instructions, trans. P.W. Harkins, Westminster, MD, 1963, pp. 9-19. For ease of reference, we will refer to each instruction according to the numbering given in Harkin's Baptismal Instructions. 
believe in the God of the universe, the Father of our Lord Jesus Christ, the cause of all things, the inexpressible ("̈ $\varphi p \alpha \sigma \tau \circ v)$, the incomprehensible

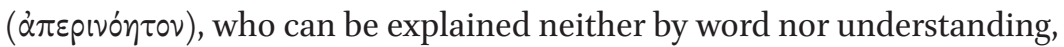
who has by His kindness and goodness created all things. ${ }^{63}$

With regards to the Son, Chrysostom affirms that He is

His only-begotten Son, our Lord, who is in all ways like and equal to the

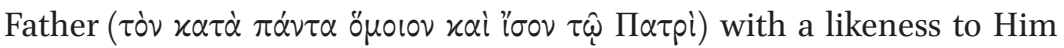

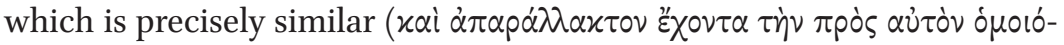

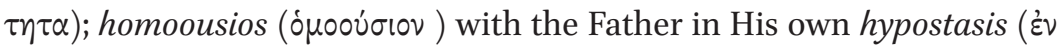
ióí $\dot{\alpha} \pi 0 \sigma \tau \dot{\alpha} \sigma \varepsilon \varepsilon)$; proceeding from the Father in a manner that cannot be

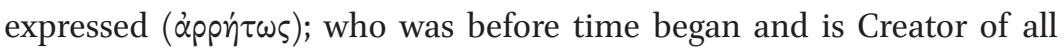
ages; who in later times, for our salvation, took the form of a slave and

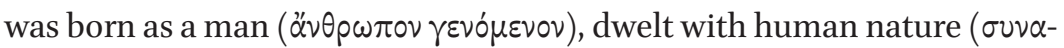
$\nu \alpha \sigma \tau \rho \alpha \varphi \varepsilon^{\prime} v \tau \alpha \tau \hat{\eta} \alpha \dot{\alpha} \theta \rho \omega \pi i v \eta \eta$ $\varphi \dot{\sigma \varepsilon l}$ ), was crucified, and rose again on the third day. ${ }^{64}$

This is a very rich confession. Like Meletius, Chrysostom assumes two epistemological premises in Trinitarian orthodoxy. The first being that faith must always precede theological understanding. ${ }^{65}$ The second and corollary is that we must recognise the inexpressibility or incomprehensibility of our Creator, which inevitably limits what we can know about God. In his depiction of the Son's relationship with the Father, Chrysostom shows himself to be the successor of diverse theological strands in Antioch. Operating as a good Neo-Nicene Meletian, he not only speaks of the Son as homoousios with the Father, but is also quite happy to use Homoian terms to depict describe Him. Thus, he says that the Son is "in all ways like (homoios) ... the Father," no doubt modifying or safeguarding the expression by taking it to mean being "equal to the Father."

63 Instruction 1.20 (John Chrysostom, Baptismal Instructions., pp. 31).

64 Ibid. 1.21 (Harkins, pp. 31, modified).

65 To be sure, the idea of faith preceding understanding is common place among the fathers. There are, nevertheless, grounds to believe that Chrysostom inherited this from Meletius. Meletius' homily, as mentioned earlier, contrasts the faith of Abraham with that of Zacharias. He then exhorts his listeners to imitate the former, not the latter, recognising that we are but "dust and ashes" whenever we discourse about God. Years later, when Chrysostom preaches his first sermon series on the Trinity and argues for the importance of faith preceding understanding, he likewise exalts Abraham as an exemplary figure, and denounces Zacharias as one who relied too much on his reason, did not believe in God's revelation, and was thus punished. Panarion 53.32.4-33.1-4; incomp. 2.11-13, 33. 
Likewise, when he speaks of the Son's "likeness" (homoiotèta) to the Father, he qualifies it by adding that the two are "precisely similar" (aparallakton).

Chrysostom's use of hypostatic language here is also characteristically Eusebian. Besides affirming that the Son subsists in his own hypostasis (en idia hypostasei), he adds that hypostatic language is a necessary safeguard against Sabellianism, a conviction that, of course, sets him apart from the Paulinians.

And if, from the other side, Sabellius desires to destroy sound doctrines by glossing over the distinction of hypostases ( $\sigma u v \alpha \lambda \varepsilon i \varphi \omega \nu \tau \dot{\alpha} \varsigma$ نं $\pi \circ \sigma \tau \dot{\alpha} \sigma \varepsilon 1 \zeta$ ), my beloved, wall up your ears against him too, and teach him that the substance of the Father, Son and the Holy Spirit is one, but that there are

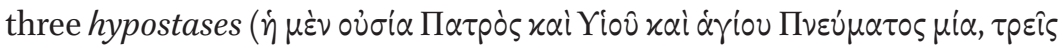
$\delta \dot{\varepsilon} \alpha i \dot{i} \pi \circ \sigma \tau \dot{\alpha} \sigma \varepsilon(\zeta) .{ }^{66}$

The Son's divinity, continues Chrysostom, can also be discerned from the power He shares with the Father.

For it is the Son Himself who said, As the Father raises up the dead and gives them life, even so the Son also gives life to whom He will, and in all

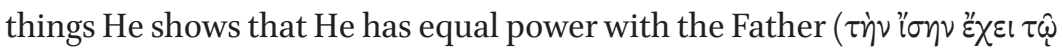

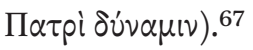

While there is no evidence of Meletius teaching that the Son's equal power with the Father implies his divinity, the logic of 'equivalence' that Chrysostom employs here is quite akin to the epistemic argument that Meletius employs in his homily. This logic of epistemic and dynamic equality, moreover, features quite often in Basil of Caesarea's defence of Christ's divinity. Basil, of course, is a good friend, student and supporter of Meletius. There is reason to believe that Chrysostom's present teaching was influenced in no small measure by Basil. The limits of this essay, unfortunately, means this relationship can only be taken up in a separate study.

The final and intriguing aspect of this confession is Chrysostom's description of the Son as not only taking on "the form of a slave," but was, in fact, "born as a man" (anthrōpon genomenon) and "dwelt with human nature" (sunanastraphenta tē anthrōpine physei). In Chrysostom's mind then, the Son and Jesus Christ is consistently one divine subject. That is to say, he teaches a unitive Christology. This is of no small significance, since it differs greatly from the

$66 \quad$ Instruction 1.22 (Harkins, pp. 31).

67 Instruction 1.22 . 
dyophysite Christology propounded by his teacher, Diodore of Tarsus. ${ }^{68}$ One wonders how Chrysostom could have gotten away with this, given Diodore's political clout in the 380 . More importantly, this calls into question the popular belief that Chrysostom was greatly influenced by Diodore. Perhaps, the truth is that Diodore was but one of Chrysostom's teachers, but not the most important.

Regarding the divinity of the Holy Spirit, Chrysostom first alludes to it in Instruction 1, by insisting that the Spirit is a hypostasis distinct from the Father and the Son. Later, in Instruction 2, he employs the logic of 'equivalence' again when he expounds on the Spirit's role in baptism. The Spirit, he argues, must be divine since He is ascribed the "same dignity ( $\tau \hat{\eta} \varsigma \alpha \hat{\tau} \tau \hat{\eta} \varsigma \alpha \xi i \alpha \varsigma)$ of the Father and Son" in the baptismal formula. This is further underscored by the baptismal ritual, whereby a catechumen is baptized three times in the one name of the "undivided Trinity." 69

Besides this, adds Chrysostom, the Spirit is also divine because He is the active agent in human salvation. Speaking on the rite of baptism, he points out that the Spirit is the only one who can "renew the [baptized] in the image of

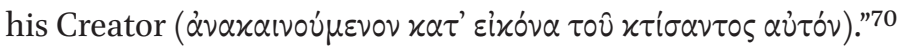

Through the words and the hand of a priest, the Holy Spirit descends upon you. Instead of the man who descended into the water, a different man comes forth, one who has wiped away all the filth of his sins, who has put off the old garment of sin and has put on the royal robe."71

Later, in Instruction 9, he likens this "the bath of regeneration and renewal by the Holy Spirit" to a divine smelting process. ${ }^{72}$

God takes this nature of ours when it is rusted with the rust of sin, when our faults have covered it with abundant soot, and when it has destroyed the beauty He puts into it in the beginning, and He smelts it anew. He

68 Dyophysite Christology predicates two very distinct subjects, one divine, the other human, to Jesus Christ. Diodore first developed this view in his Christological debates with Apollinarius. For a helpful discussion on the historical scholarship on Chrysostom's Christology, see Naidu, Transformed in Christ., pp. 85-88; Lawrenz, Christology of John Chrysostom, pp. 175; Beeley, "Early Christological Controversy."

69 This, of course, parallels Basil's argument in his On the Holy Spirit 12. Chrysostom, Instruction 2.26 .

$70 \quad$ Ibid. For the same motif, see also Ibid. 2.11 (Harkins, pp. 47).

$71 \quad$ Instruction 2.25 (Harkins, pp. 52).

$72 \quad$ Instruction 9.12 . 
plunges it into the waters as into the smelting furnace and lets the grace of the Spirit fall on it instead of the flames. Then He brings us forth from the furnace, renewed like newly-moulded vessels, to rival the rays of the sun with our brightness. He has broken the old man to pieces but has produced a new man who shines brighter than the old. ${ }^{73}$

Henceforth, the baptized become "a dwelling place for the Holy Spirit," and

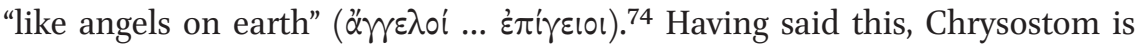
also clear that salvation is not so much a change in the human ousia but a restoration of it into its pristine condition. This is achieved primarily through the remaking of the human will ( $\tau \dot{\eta} \nu \pi \rho \circ \alpha i p \varepsilon \sigma \nu \nu \mu \varepsilon \tau \alpha \sigma \kappa \varepsilon v \dot{\alpha} \sigma \alpha \sigma \alpha$ ), whereby the mist, which blinded the baptised' eyes previously, dissipates, and "God's grace [makes] them see the ugly deformity of evil and virtue's shining beauty as they truly were." 75 This relationship between the Spirit's soteriological role and His divinity has rich Basilian overtones, of course, and again deserves a separate treatment.

\section{Conclusion}

For too long, Chrysostom has been regarded simply as an Antiochene theologian, who is more a pastor and moralist than a serious theologian. When we study Chrysostom's Trinitarian doctrine in the context of the Eusebian-Meletian traditions, a different picture emerges. First of all, the theological epistemology and structure assumed in Chrysostom's Trinitarian doctrine: the priority of faith before reason, his doctrine of divine incomprehensibility, his adoption of the Nicene homoousios formula, and his use of hypostatic language as a safeguard against Sabellianism are ample evidence that he was operating within the lineages of the Eusebians and Meletians. Secondly, the ease by which he uses Eusebian and Homoian expressions also indicates that he has taken on board the reconciling stance exemplified by Meletius. ${ }^{76}$ Most intriguingly, his Christological departure from Diodore calls into question his theological indebtedness to the Bishop of Tarsus. Finally, we alluded also to the

73 Ibid. 9.23 (Harkins, pp. 139).

74 Instruction 2.27 .

75 Instruction 4.14 (Harkins, pp. 71).

76 The term, aparallakton, is used no less than 20 times in a Trinitarian context in Chrysostom's Homilies on Matthew and John, his Homilies Against the Anomeans, his Baptismal Instructions and his Pauline homilies. 
potential influence that Basil has on Chrysostom, the details of which can only be addressed separately. When all these are taken into account, Chrysostom should be better understood as a Neo-Nicene Eusebian-Meletian theologian rather than a representative of the School of Antioch, which he is commonly misunderstood.

\section{Bibliography}

Allen, Pauline. 'John Chrysostom after Chalcedon: A Useful Ecumenist?' In John Chrysostom: Past, Present, Future, edited by Doru Costache and Mario Baghos, 53-70. Sydney: AIOCS, 2017.

Augustine. Four Anti-Pelagian Writings. Translated by John A. Mourant and William J. Collinge. Washington D.C.: Catholic University of America Press, 2001.

Ayres, Lewis. Augustine and the Trinity. Cambridge: Cambridge University Press, 2010.

Barnard, Lawrence Reginald. 'Christology and Soteriology in the Preaching of John Chrysostom'. Southwestern Baptist Theological Seminary, 1974.

Beckwith, Carl. Hilary of Poitiers on the Trinity: From De Fide to De Trinitate. Oxford; New York: Oxford University Press, 2011.

Beeley, Christopher. Gregory of Nazianzus on the Trinity and the Knowledge of God:In Your Light We Shall See Light. Oxford, New York: Oxford University Press, 2008.

Beeley, Christopher. 'The Early Christological Controversy: Apollinarius, Diodore, and Gregory Nazianzen', Vigiliae Christianae, 65 (2011): 376-407.

Behr, John. The Nicene Faith. Vol. 1. Crestwood, N.Y.: St. Vladimir's Seminary Press, 2004. Behr, John. The Nicene Faith. Vol. 2. Crestwood, N.Y.: St. Vladimir's Seminary Press, 2004. Campenhausen, Hans von. The Fathers of the Church. Peabody, Massachusetts: Hendrickson, 1998.

Delcogliano, Mark. 'George of Laodicea: A Historical Reassessment'. Journal of Ecclesiastical History 62, no. 4 (2011): 667-92.

Delcogliano, Mark. 'The Death of George of Laodicea'Journal of Theological Studies 6o, no. 1 (2009): 181-90.

Delcogliano, Mark. "The Influence of Athanasius and the Homoiousians on Basil of Caesarea's Decentralization of "Unbegotten"'. Journal of Early Christian Studies 19, no. 2 (2011): 197-223.

Delcogliano, Mark, and Andrew Radde-Gallwitz. 'Introduction'. In Against Eunomius, Vol. 122. Fathers of the Church. Washington, D.C.: Catholic University of America Press, 2011.

Epiphanius. The Panarion of Epiphanius of Salamis. 2nd, rev. ed. Leiden: Brill, 2013. Greer, Rowan A. Theodore of Mopsuestia: Exegete and Theologian. London: The Faith Press, 1961. 
Grenz, Stanley. Rediscovering the Triune God: The Trinity in Contemporary Theology. Minneapolis: Fortress Press, 2004.

Gwynn, David M. The Eusebians: The Polemic of Athanasius of Alexandria and the Construction of the 'Arian Controversy'. Oxford: Oxford University Press, 2006.

Hildebrand, Stephen M. The Trinitarian Theology of Basil of Caesarea: A Synthesis of Greek Thought and Biblical Truth. Washington, DC: Catholic Univ. of America Press, 2007 .

Illert, Martin.Johannes Chrysostomus und das antiochenisch-syrische Mönchtum: Studien zu Theologie, Rhetorik und Kirchenpolitik im antiochenischen Schriftum des Johannes Chrysostomus. Zürich: Pano-Verl., 2000.

Jean Chrysostome. Huit Catéchèses Baptismales Inédites. Translated by Antoine Wenger. Paris: Ed. du Cerf, 1957.

John Chrysostom. Baptismal Instructions. Translated by Paul W Harkins. Westminster Md.: Newman Press, 1963.

Juzek, J.H. Die Christologie Des Hi. Johannes Chrysostomus: Zugleich Ein Beitrag Zur Dogmatik Der Antiochener. Bresau, 1912.

Karmann, Thomas. 'Johannes Chrysostomus Und Der Neunizänismus Eine Spurensuche in Ausgewählten Predigten Des Antiochenischen Presbyters', Sacris Erudiri, 51 (2013): $5^{-20 .}$

Karmann, Thomas R. Meletius von Antiochien: Studien Zur Geschichte Des Trinitätstheologischen Streits in Den Jahren $360-364$ N. Chr. Frankfurt: Peter Lang, 2009.

Kelly, J.N.D. Golden Mouth: The Story of John Chrysostom - Ascetic, Preacher, Bishop. Ithaca, N.Y.: Cornell University Press, 1995.

Lawrenz, Melvin E. The Christology of John Chrysostom. Lewiston: Mellen University Press, 1996.

Liebeschuetz,J.H.W.G. Ambrose and John Chrysostom: Clerics between Desert and Empire. Oxford; New York: Oxford University Press, 2011.

Lienhard, Joseph T. 'Ousia and Hypostasis: The Cappadocian Settlement and the Theology of "One Hypostasis"'. In The Trinity: An Interdisciplinary Symposium on the Trinity, edited by Stephen Davis, Daniel kendall, and Gerald O'Collins. Oxford: Oxford University Press, 2002.

Lienhard, Joseph T., Michel Barnes, and Rowan Williams. 'Did Athanasius Reject Marcellus?' In Arianism after Arius: Essays on the Development of the Fourth Century Trinitarian Conflicts. Edinburgh: T \& T Clark, 1993.

Louth, Andrew. 'Why Did the Syrians Reject the Council of Chalcedon?' In Chalcedon in Context: Church Councils, 400-70o, edited by R.M. Price and Mary Whitby. Liverpool: Liverpool University Press, 2009.

McLeod, Frederick G. The Image of God in the Antiochene Tradition. Washington, D.C.: Catholic University of America Press, 1999.

McLeod, Frederick G. Theodore of Mopseustia. London and New York: Routledge, 2009. 
McLeod, Frederick G. The Roles of Christ's Humanity in Salvation: Insights from Theodore of Mopseustia. Washington, D.C.: The Catholic University of America Press, 2005.

Naidu, Ashish J. Transformed in Christ: Christology and the Christian Life in John Chrysostom. Princeton Theological Monograph Series. Oregon: Wipf \& Stock, 2012.

Papadopoulos, S.G. 'The Holy Trinity and the Parousia of the Holy Spirit According to St. John Chrysostom'. In Agape and Diakonia. Essays: In Memory of Bishop Gerasimos of Abydos, 97-125. Brookline, MA: Holy Cross Orthodox, 1998.

Parvis, Sara. Marcellus of Ancyra and the Lost Years of the Arian Controversy, 325-345. Oxford: OUP, 2009.

Rashdall, H. The Idea of the Atonement in Christian Theology, Being the Bampton Lectures for 1915. London: MacMillan, 1919.

Sesboüé, Bernard. Saint Basile et La Trinité, Un Acte Théologique Au Ive Siècle : Le Rôle de Basile de Césarée Dans L'élaboration de La Doctrine et Du Langage Trinitaires. [Paris]: Desclée, 1998.

Spoerl, Kelley McCarthy. 'The Schism at Antioch since Cavallera'. In Arianism after Arius : Essays on the Development of the Fourth Century Trinitarian Conflicts, edited by Michel Barnes and Rowan Williams. Edinburgh: T \& T Clark, 1993.

Sullivan, Francis Aloysius. The Christology of Theodore of Mopsuestia. Analecta Gregoriana. Romae, Apud Aedes Pont: Universitatis Gregorianae, 1956.

Wallace-Hadrill, D.S. Christian Antioch: A Study of Early Christian Thought in the East. Cambridge: Cambridge University Press, 1982.

'Web Bibl Dec 2016 - Chrysostom Bibliography March 2016.pdf'. Accessed 29 September 2016 <http://www.cecs.acu.edu.au/Chrysostom\%2oBibliography\%2oMarch\%20 2016.pdf $>$.

Williams, Rowan. Arius : Heresy and Tradition. Rev. ed. Grand Rapids Mich.: W.B. Eerdmans, 2002.

Young, Frances M. From Nicaea to Chalcedon: A Guide to the Literature and Its Background. London: SCM, 1983.

Zachhuber, Johannes. 'The Antiochene Synod of AD 363 and the Beginnings of NeoNicenism'. Zeitschrift Für Antikes Christentum 4 (n.d.): 83-101. 